\title{
Why Homicides are Committed in Russia: Quantitative Explanation
}

\author{
Ivan S. Skifsky*
}

Tyumen State Oil and Gas University, Tyumen Region, Tyumen, Volodarskogo Street, 38, 625000, Russia

Abstract: A paper dedicates to results of criminological research of determining factors of homicides, committed in contemporary Russia.

Keywords: Criminal violence, Criminological determination, Statistical modeling.

Currently criminal aggression is on increase in Russia. Issues of domestic violence against women and children, cruelty in police, army, prisons and educational institutions are becoming topical there. Regular national mass media reports of new killings, assaults, kidnapping have become the norm of Russian reality (Davidenko 2012; Hohlov 2012; Kanev 2012; Sergeev 2012). On the other hand in public statements and official documents there is a report on annual decrease of crime rate and victimization level of citizens.

In 2009, the Minister of Ministry of Interior in interview to "Nezavisimaya Gazeta" made several important statements: "I can confirm facts and figures that today the Ministry effectively fights the criminal world and adequately responds to new threats". "A new criminal revolution will not happen. In Russia there is quite another socio-political situation - crime is reducing". "All this time we are actively engaged in crime prevention and improved methods of activity to confidently say today - we will not allow crime rate increasing" (Tverdov 2009). Vice-Minister agreed with him, indicating that purposeful work of all concerned state authorities allow to minimize negative criminal manifestations (Rossiyskaya Gazeta 2010). However, the newest researches of leading criminologists (Gilinsky, Inshakov, Luneev, Ovchinskiy) prove the opposite - there are no grounds for decreasing violent crime rate in Russia.

With its high, excessive destructiveness certain forms of aggressive behavior often have irreversible consequences, for example: loss of ability to work by injured or destruction of property. From the standpoint of interests of an individual, reflected in the normative ranking of criminal offenses intentional deprivation of life is an extreme form of socially dangerous violence.

*Address corresponding to this author at the Tyumen State Oil and Gas University, Tyumen Region, Tyumen, Volodarskogo street, 38, 625000, Russia; Tel/Fax: (3452) 20-84-56; E-mail: skifsky@mail.ru
According to authoritative experts assessments, up to 50 thousands of homicides is annually committed in Russia with increasing number of missing people, unidentified bodies (Ovchinskiy 2011). Luneev (2011:350, 369) asserts, that in 1992-2007 there were only recorded 477 thousands of homicides, 296 thousands of convicted and 180 thousands of killers in search (38\%). Taking into account latent acts and flexible statistics these figures should be doubled or tripled. The motivation of murderers is rationalized and forms of crime become more and more sophisticated.

\section{WHAT ARE THE DETERMINANTS OF HOMICIDES IN RUSSIA?}

According to data of $\mathrm{WHO}$ Regional Office for Europe, Russia has first place in number of murders of young people. The international report notes that the highest level of violent deaths is recorded in low-and middle-income countries. Among the powerful risk factors for violence are: social inequality, poverty (deprivation), the availability of alcohol, illicit drug trafficking (Sethi et al. 2010:12-13, 28). Analysis of national scientific literature shows that qualitative research of crime determination involves only enumeration, intuitive ranking, characterization and individual assessment of separate criminogenic phenomena. In particular, Antonyan (2004) considers that this includes: sharp stratification of society, lack of economic development, poor quality of life, loss of government patronage, depression and anxiety, ethnoreligious conflicts, negative effects of irregular migration and globalization, unemployment and others. Agapov (2011) justifies the following factors of violent crime, including homicide. Serious deformation in spiritual and moral sphere of much of the population, adverse changes in social psychology, weak legal framework of business regulation, elimination of soviet system of crime prevention. Qualitative analysis of crime structure allows Vandyshev (2000:310) to conclude that reproduction of criminal aggression in Russia is caused by national traditions of violence 
(state, public, domestic), status of social and moral requirements in society, poverty, low level of culture, risk to be a victim of crime, intensive alcoholism and narcotism, latency of crime, impunity of perpetrators, shortcoming in the protection of public order and safety of citizens, influence of criminal subculture and illegal possession of weapon (Criminology 1994:252-253).

Such traditional approach has significant shortcomings. Firstly, it doesn't reflect the real "weight" of each determining factor in genesis of social pathology and secondly, it doesn't take into account very likely changes in space-time continuum (Skifsky 2007).

It becomes apparent that quantitative and statistical measure of the determinants of criminogenic effect is a prerequisite for criminological research. Without downplaying the role of qualitative research in criminology, it should be recognized that using only descriptive methods doesn't allow verifying the reliability of even the most convincing results. Considering this fact, author turned to model of crime proposed by Olkov (2008: 31, 35): $y=f\left(x_{1}, x_{2}, x_{3} \ldots x_{n}\right)$, where $y$-crime rate, including reported and latent acts (dependent variable); $x_{1}, x_{2}, x_{3} \ldots x_{n}$ - factors that explain criminal behaviour (independent variables). Destructive illegal behaviour can be represented as product of three sets of forces: $Y=f\left(F_{a}, F_{b}, F_{c}\right)$, where $Y-$ vector of individual or social group behaviour, $F_{a}=$ $\left\{a_{1}, a_{2}, a_{3} \ldots a_{n}\right\}$ - set of cosmo-telluric forces of the environment (solar activity, atmospheric pressure, temperature, precipitation and other meteorological conditions); $F_{b}=\left\{b_{1}, b_{2}, b_{3} \ldots b_{n}\right\}-$ set of unconditioned biological forces; $F_{c}=\left\{c_{1}, c_{2}, c_{3} \ldots c_{n}\right\}$ - set of social forces. These forces aren't equally affecting deviant behaviour - primary role belongs to group of social factors which are subject to criminological modeling to quantify their impact on dynamics of negative deviance. The efficiency of this model, which allows to measure criminogenic effect of any factor is confirmed by results of criminological and deviantological research.

Using statistical modeling, we established significant relationships between violent crime, corruption and income inequality; sexual aggression and migration; suicide and unemployment; robbery and alcohol consumption (Olkov 2004, 2006; Skifsky 2007, 2010; Juzihanova 2005, 2006; Bezrukov et al. 2004).

In the context of present research the dependent variable $y$ is represented by homicides committed and reported in Russia. The independent variables $x$ are represented by the following social indicators which can be measured quantitatively:

$x_{1}$ - income inequality - measured by Gini index. It expresses the degree of deviation of line of factual distribution of total income from the line of equal distribution. The coefficient can range from 0 to 1 , thus, the higher its value, the more unequally distributed income in society (in units);

$x_{2}$ - unemployment - indicator showing number of persons officially registered in the employment service (in thousands);

$x_{3}$ - dynamics of convicts - indicator showing number of persons sentenced by court to various types of criminal punishment (in thousands);

$x_{4}$ - voluntary migration - indicator showing number of migrants arrived in Russia (in thousands);

$x_{5}$ - forced migration - indicator showing number of asylum seekers arrived in Russia (in thousands);

$x_{6}-$ alcohol consumption per capita (in liters);

$x_{7}, x_{8}-$ alcoholism and alcoholic psychoses, drug addiction - indicators showing number of patients registered in health-care settings with appropriate diagnosis (in thousands).

Data array generated from official statistics of Rosstat, Ministry of Interior of Russia, World Income Inequality Database (WIID), Global Information System on Alcohol and Health (GISAH).

Based on initial qualitative research of indicators, characterized homicide rate in Russia (1980-2010), author has formulated working hypothesis that between dependent variable $y$ and each independent variable $x$ exists positive criminologically significant relationship. Hypothesis testing by means of statistical modeling carried out by performing a binary regressioncorrelation analysis, revealing factors mainly determine the variation of resultant - commission of homicide in Russia.

Research allowed to establish relationship between homicide and income inequality (1980-2010), described by equation: $y=92,346 x_{1}-9,5505$ at $R^{2}=0,63, R_{y x}=$ $79 \%, F(1,29)=49,74$ (Figure 1). It follows, when Gini index is changed to 0,1 homicide rate in Russia is averagely increased by 9,2 thousands of offences. This result isn't unexpected. According to Director of the 


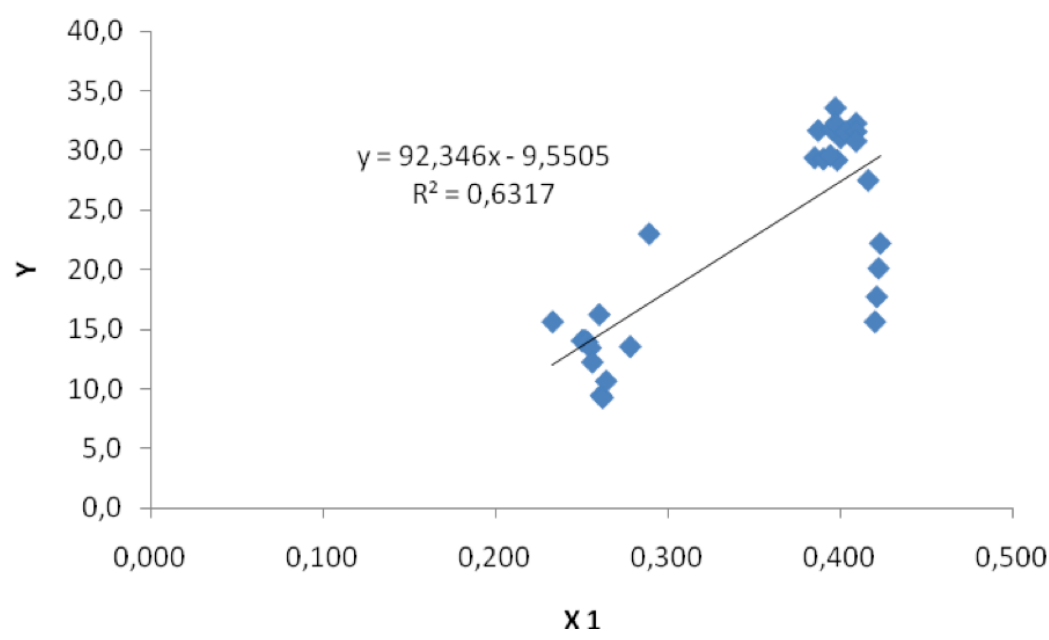

Figure 1: Relationship between homicide and income inequality in Russia (1980-2010).

Institute of Economics of Russian Academy of Science Grinberg, the middle class in Russia, amounting to about $20 \%$, is virtually absent, the super-rich $-2 \%$, almost all the rest can be attributed to those who struggle for existence. The country observed the phenomenon of "poor workers" who receive wages of less than 10 thousands of rubles per month (Bashkatova 2011). Analyzing data of Rosstat, Gilinsky (2010) leads impressive figures: in Russia $41,2 \%$ of beggars, $49,7 \%$ of poor, $8,4 \%$ of wealthy, $0,7 \%$ of rich. The consternation isn't only in wild poverty of most Russians but also in incomprehension of the whole tragedy of their "exclusion". In unprecedented polarization of incomes the desire of individual to improve financial situation looks quite natural, however his chosen way of overcoming inequality may not fit within framework of the law-abiding behavior.

Further, relationship is found between homicide and alcohol consumption (1980-2008), expressed by equation: $y=3,0213 x_{6}-3,5303$ at $R^{2}=0,58, R_{y x}=76$
$\%, F(1,27)=37,47$ (Figure 2). Its interpretation allows a conclusion that when alcohol consumption is changed to 1 liter per capita, homicide rate in Russia is averagely increased by 3 thousands of illegal acts. According to estimates of WHO and Health Ministry of Russia, alcohol consumption in excess of 8 liters of pure alcohol per capita per year is dangerous to public health. On various departmental estimates alcohol consumption per capita in Russia range from 10 to 18 liters per year. According to expert estimates (Nemtsov 2009), real alcohol consumption is about $12-13$ liters, while the factitious overestimate of this indicator is necessary for report on reducing of alcohol abuse population in coming years.

Minister of Health and Social Development of Russia believes that the successful implementation of public policy concept of reducing alcohol abuse and alcoholism prevention (approved by the Government of the Russian Federation in 2009) will reduce alcohol consumption per capita to 14 liters. For the period

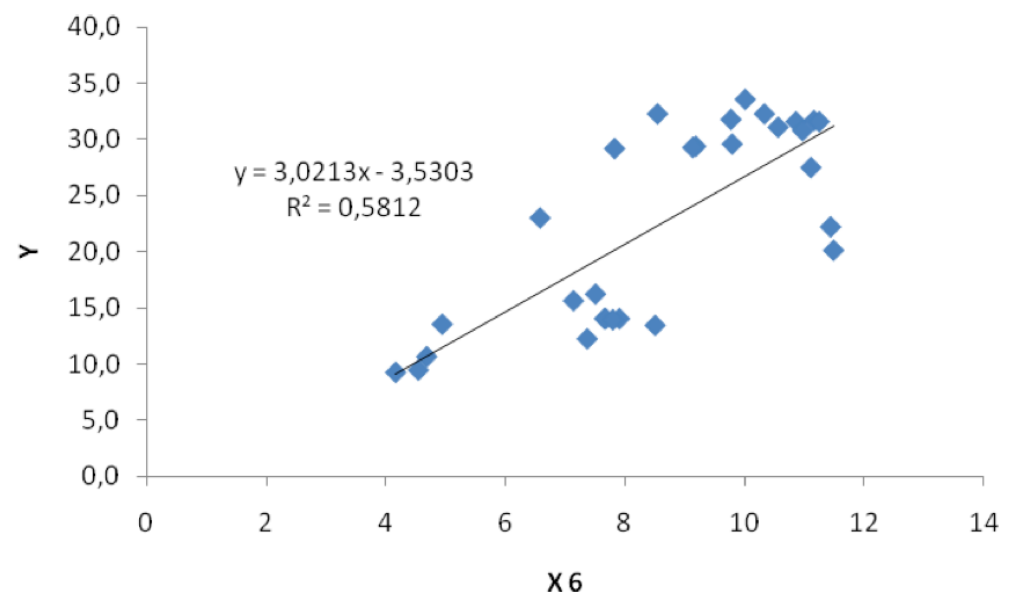

Figure 2: Relationship between homicide and alcohol consumption in Russia (1980-2008). 


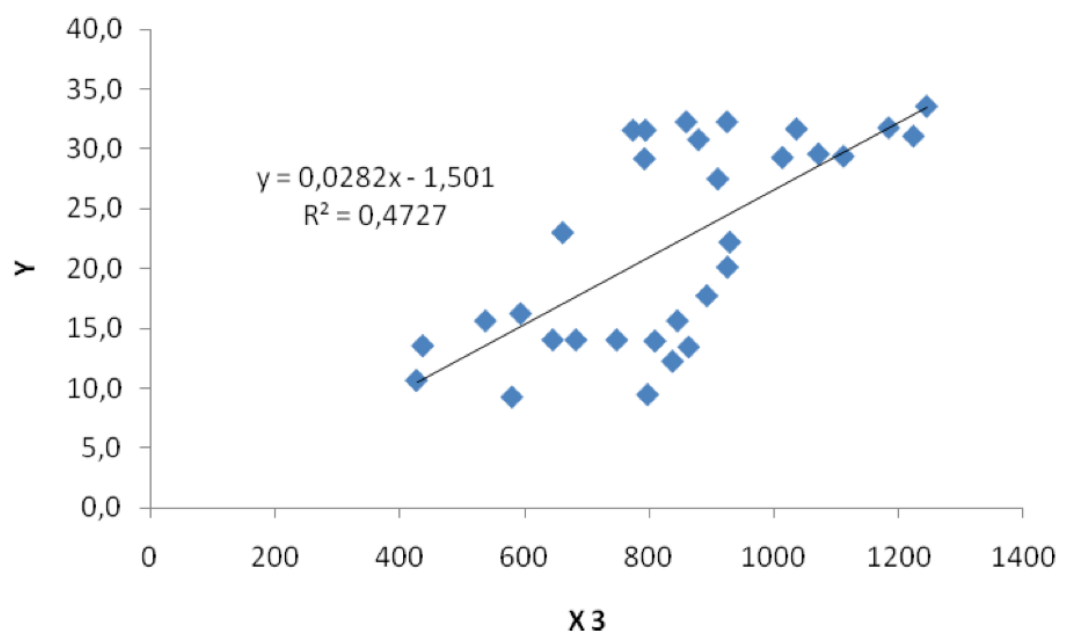

Figure 3: Relationship between homicide and dynamics of convicted in Russia (1980-2010).

2013-2020 put even more ambitious goals - the elimination of illegal alcohol market and the reduction of alcohol consumption per capita by $55 \%$.

Author found a moderate relationship between homicide and dynamics of convicted (1980-2010), described by equation: $y=0,0282 x_{3}-1,501$ at $R^{2}=$ $0,47, R_{y x}=69 \%, F(1,29)=25,99$ (Figure 3). It follows that when a factor is changed to 100 thousands of offenders, the death rate from intentional attacks in Russia is averagely increased by 2,8 thousands of crime. According to Antonyan (2011:288), among murderers there is a high proportion of repeat offenders serving sentence of actual imprisonment. Mercenary crimes are usually committed within one year after release, while realization of intention to deprive the victim's life requires accumulation and exacerbation of internal conflicts causing severe traumatic experiences. Severe punishment for its content doesn't imply social correction. Getting in detention for long periods a person becomes participant of penitentiary microenvironment, significantly distorting the scale of ideals and values of law-abiding citizen. For this reason, an individual being released is driven by set of biological, cosmo-telluric and social factors; maximally conscious of income inequality; tries to overcome it by most accessible and cost-effective way. Obviously absence of effective resocialization system of convicts accompanied by broad promotion of criminal subculture in Russian society, minimizes efforts of law enforcement agencies to prevent recidivism (Skifsky 2009).

The results of criminological modeling shows moderate positive relationship between homicide and drug addiction (1980-2009), illustrated by equation: $y=$ $0,0367 x_{8}+16,858$ at $R^{2}=0,37, R_{y x}=61 \%, F(1,28)=$ 16,44 (Figure 4). It follows that when the sociopath rate is changed to 10 thousands of addicts, homicide rate in Russia is averagely increased by 0,4 thousands of acts.

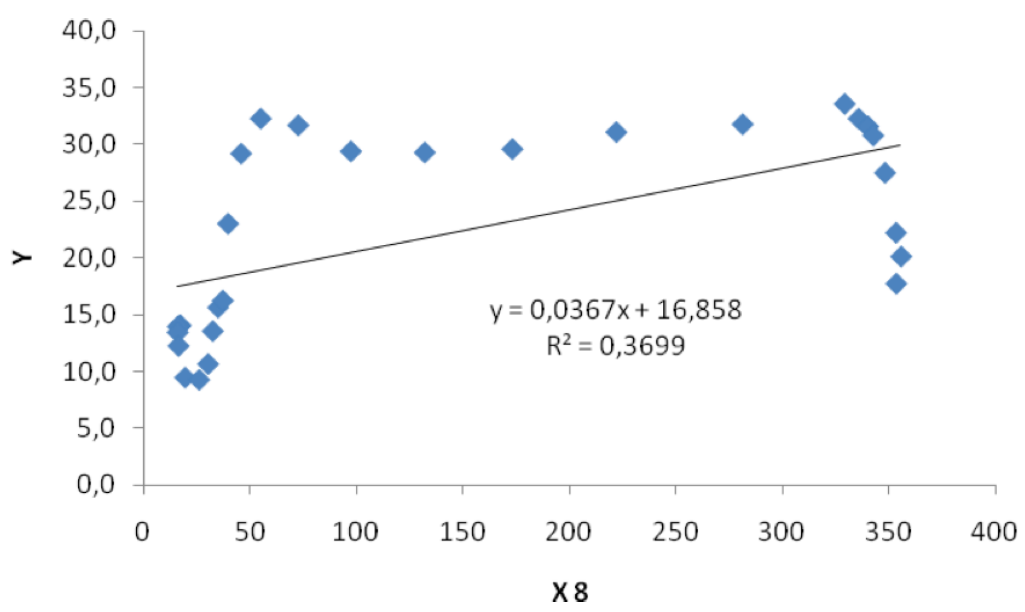

Figure 4: Relationship between homicide and drug addiction in Russia (1980-2009). 
According to classification of crime related to and generated by drug trafficking developed by Romanova (2009:135-136), aggressive and violent acts which are committed by drug addicts in state of narcotic intoxication form a separate group. Such individuals pose a real threat of physical harm to both themselves and other people. Exaggerated fear often pushes deviants in unpredictable and irrational behavior. According to data of Health Ministry of Russia and Rosstat, the number of drug addicts registered in hospitals are increasing annually and are amounted to more than 350 thousands of patients.

Experts of the UN Office on Drugs and Crime say that drug addicts of Russia occupy first place in the world, in terms of heroin consumption. In the past 10 years it has increased by 10 times. In Russia the demand for Afghan heroin has increased so much that now it is rather a destination than a transit country (Drug addiction... 2009).

The role of other factors analyzed in homicide determination - unemployment $\left(R^{2}=0,14, R_{y x}=37 \%\right)$, voluntary $\left(R^{2}=0,03, R_{y x}=-19 \%\right)$ and forced migration $\left(R^{2}=0,10, R_{y x}=32 \%\right)$, alcoholism and alcoholic psychosis $\left(R^{2}=0,28, R_{y x}=-53 \%\right)$ - isn't statistically significant.

Summing up, the established statistically reliable and criminological significant causal relationships between variables; it can be concluded that the most determining factors of homicides committed in contemporary Russia are income inequality, alcohol consumption, drug addiction and dynamics of convicts.

\section{REFERENCES}

Agapov, Alexandr F. 2011. "Violent Crime and Its Prevention." Pp. 237-255 in Criminology: Textbook. 2nd ed., edited by V.D. Malkov. M.: Justitsinform.

Antonyan, Jury M. 2004 "The Concept of Crime Causes and Causes of Crime in Russia." Journal of Russian Investigator 8:30-32.

Antonyan, Jury M. 2011. Specially Dangerous Offender. M.: Prospekt.

Bashkatova, Anastasia. 2011. "Rich Russia With Low Earnings," Nezavisimaya Gazeta, April 12, p. A-6.

Bezrukov, Denisenko, Olkov and Juzihanova, eds. 2004. Fundamental and Application Study of Crime and Management of Internal Affairs. Tyumen: Vector Book.
Criminology. 1994. M.: MSU.

Davidenko, Vadim. 2012 "Two Police Officers Injured in Car Explosion in Ingushetia," Rossiyskaya gazeta, July 28, p. A8.

Drug Addiction, Crime and Insurgency. Transnational Threat of Afghan Opium. Summary. 2009. UNODC.

Gilinsky, Yakov I. 2010. Permanently Excluded. Retrieved April 1, 2012 (http://deviantology.spb.ru/etc/publications/GilinskyIskluchennye_navsegda.pdf).

Hohlov, Dmitriy. 2012. "Serial Rapist Arrested in Ivanovo," Rossiyskaya Gazeta, August 1, p. A-6.

Juzihanova, Elvira G. 2005. Modeling of Criminogenic Processes in Subjects of the Russian Federation. Tyumen: Vector Book.

Juzihanova, Elvira G. 2006. "Elasticity of Crime and Causal Relationships Modeling in Criminology." State and Law 2:9699.

Kanev, Sergey. 2012. "Kidnapping. Homicide. Escape," Novaya Gazeta, July 25, p.A-5.

Luneev, Victor V. 2011. The Course of World and Russian Criminology. Special part. Vol. 2. M: Urait.

Olkov, Sergey G. 2004. "Benefits and Harms of Inequality (Criminological Research)." State and Law 8:73-78.

Olkov, Sergey G. 2006. Mathematical Modeling in Law, Ethics and Deviantology. Tyumen: TGNGU-TNC SO RAN.

Olkov, Sergey G. 2008. Analytical Criminology (Lectures). 2nd ed. Kazan: Poznanie.

Ovchinskiy, Vladimir. 2011. "The Real Crime is Several Times Higher Than Official," Moscovsky Komsomolets, March 31, p. A-5.

Nemtsov, Alexandr V. 2009. Alcohol History of Russia: The Newest Period. M: LIBROKOM.

Romanova, Larisa I. 2009. Drug Crime: Criminological and Criminal Characteristics. 2nd ed. Vladivostok: Dalnevostochniy University.

Rossiyskaya Gazeta. 2010. Newspaper editorial. July 10, p. A-5.

Sergeev, Nikolay. 2012. "Term for Murder of the Governor is Insensible," Kommersant, August 10, p. A-2.

Sethi, Hughes, Bellis, Mitis and Racioppi, eds. 2010. European Report on Preventing Violence and Knife Crime Among Young People. Geneva: WHO Press.

Skifsky, Ivan S. 2007. Violent Crime in Contemporary Russia: Explanation and Prediction. Tyumen: Vector Book.

Skifsky, Ivan S. 2009. "Criminal Punishment Efficiency and Its Influence Upon Violent Crime." Modern Law Journal 5:104107.

Skifsky, Ivan S. 2010. "Research of social factors of suicides by means of statistical modeling." Pp. 172-174 in Deviant Behaviour in Contemporary World. Vladimir.

Tverdov, Peter. 2009. "Rashid Nurgaliev: "We Will Not Allow Crime Rate Increasing," Nezavisimaya Gazeta, February 10, p. A-7.

Vandyshev, Valeriy V. 2000. "Criminal Violence in Russia." Pp. 286310 in Criminology - XX century, edited by. V.N. Byrlakov, V.P. Salnikov. SPb: Juridical Center Press.

Received on 14-07-2012

Accepted on 02-10-2012

Published on 15-10-2012

\section{DOI: http://dx.doi.org/10.6000/1929-4409.2012.01.9}

(C) 2012 Ivan S. Skifsky; Licensee Lifescience Global.

This is an open access article licensed under the terms of the Creative Commons Attribution Non-Commercial License (http://creativecommons.org/licenses/by-nc/3.0/) which permits unrestricted, non-commercial use, distribution and reproduction in any medium, provided the work is properly cited. 